\title{
O debate sobre a fundação dos cursos jurídicos no Brasil (1823-1827) \\ Uma reavaliação
}

\section{The Debate on the Creation of Law Courses in Brazil (1823-1827)}

\section{A Reassessment}

Bistra Stefanova APOSTOlOVA

Faculdade de Direito

Universidade de Brasilia

Campus Darcy Ribeiro, Brasilia, DF, 70.910-900, Brasil apostolova.unb@gmail.com

Resumo O presente artigo discute a criação das primeiras academias de direito no país, fruto de um rico debate realizado em dois períodos da primeira década pós-independência: em 1823, na Assembleia Constituinte, e em 1826-1827, na Assembleia Geral. O objeto se concentra nos debates parlamentares dos quais resultou a Lei de 11 de agosto de 1827. O principal objetivo é investigar de que forma os projetos que tramitaram nas duas Assembleias se inseriam nos processos de construção do Estado e da nação, iniciados com a emancipação política do Brasil, e se a lei aprovada se afastou ou não da concepção do ensino jurídico português. $\mathrm{O}$ argumento central defende que houve diferenças entre os modelos de ensino jurídico da Constituinte e da Assembleia Geral, fruto das rápidas mudanças que ocorreram no contexto político do Primeiro Reinado. Ao fim, a nova lei conseguiu, apenas em parte, afastar-se da tradição jurídica portuguesa.

Palavras-Chave cursos jurídicos, debates parlamentares (1823, 1827), Estado nacional 
Abstract This article discusses the creation of the first law schools in Brazil, resulting from debates that took place during the first postIndependence decade: first in the Constitutional Assembly (1823) and then in the General Assembly (1826-1827). The study focuses on the parliamentary debates that resulted in the Act of August 11, 1827. The main objective is to investigate how the projects discussed by the two assemblies were part of the processes of state-building and nation-building, initiated with Brazil's political emancipation, and whether or not the approved law moved away from the Portuguese concept of legal education. The central argument states that there were differences between the models of legal education approved by the Constitutional Assembly and the General Assembly, due to the fast changes that occurred in the political context of Pedro I's reign. Ultimately, the new law managed to move away only partially from the Portuguese legal tradition.

KEYwORDS law courses, parliamentary debates (1823, 1827), Nation-State

\section{INTRODUÇÃO}

É frequente a observação na literatura que o projeto de criação dos cursos jurídicos no Brasil independente estava relacionado à formação do Estado nacional. ${ }^{1}$ Como a ideia geralmente é anunciada de forma bastante genérica, nesse artigo nos propomos a examiná-la à luz das fontes e das pesquisas de algum modo a ela conectadas. Qual é a relação entre a fundação das primeiras academias de direito e o surgimento do Estado brasileiro? Para um detalhamento melhor da questão e na busca de um esclarecimento mais aprofundado propomos separar os processos de construção do Estado e da nação. Ademais, como a lei fundadora dos primeiros cursos jurídicos - a Lei de 11 de agosto de 1827 - foi resultado de longas discussões que ocorreram na Assembleia Geral (1826-1827),

1 Ver, nesse sentido, os artigos do livro organizado por Aurélio Wander Bastos. BASTOS, 1978. 
mas que foram iniciadas na Assembleia Constituinte (1823), consideramos oportuno tratar os dois debates em separado, em função das relevantes diferenças constatadas no decorrer da pesquisa entre os dois debates e os períodos históricos nos quais estavam inseridos.

Assim, o objeto do presente estudo tornou-se a análise dos debates parlamentares sobre a criação dos cursos jurídicos no país. Esse período pós-independência foi marcado por turbulência política, intensas disputas e negociações sobre a criação da nação brasileira e a definição de um perfil do Estado nacional, capaz de garantir a unidade territorial e política. Formar quadros para gerir o novo Estado e criar uma nova identidade em oposição à identidade portuguesa foram questões decisivas naquele momento. Ademais, nesse curto período de tempo abordado na pesquisa ocorreram significativas transformações no contexto político que remetiam ao crescente desgaste e impopularidade de d. Pedro I, ao fortalecimento da Assembleia Geral diante do poder executivo, ao avanço do processo de construção do Estado nacional. Esses fatos tiveram relevantes consequências nas discussões dos representantes da nação, nas suas representações do passado e no modelo de ensino jurídico proposto para o Brasil.

O objetivo principal desta investigação remete às finalidades da instalação dos cursos jurídicos no país, em especial, à relação destes com os processos de construção do Estado e da nação brasileira. O objetivo específico é investigar se houve ou não inovação da legislação que marca o nascimento dos cursos jurídicos no Brasil em relação aos estudos de direito na Universidade de Coimbra. Afinal, a maioria dos parlamentares que participou dessa iniciativa era formada em Coimbra, fato que acabou delimitando os parâmetros das propostas sobre a concepção dos futuros estabelecimentos de ensino superior. Na definição dos objetivos da pesquisa teve papel importante a decisão da Assembleia Constituinte de manter no Brasil a vigência da legislação portuguesa até a elaboração de um ordenamento jurídico nacional. $\mathrm{O}$ fato, já instigante em si, suscitou o interesse em pesquisar como essa opção iria refletir-se no momento da fundação das primeiras academias de direito. 
Especificamente sobre a criação dos cursos jurídicos no Brasil, a literatura é escassa, tanto na área da história como na sociologia e no direito. A presente investigação dialogou com esta literatura em diversos momentos. Cabe destacar nesta produção intelectual os trabalhos Alberto Venancio Filho (1982), Aurélio Wander Bastos (1978), José Murilo de Carvalho (2004), Lilia Schwarcz (1993) e Sérgio Adorno (1988). Esta literatura, no entanto, não deu ênfase a um aspecto que constituiu a preocupação central deste trabalho. Isto é, examinar até que ponto houve inovação ou manutenção integral da tradição jurídica portuguesa nos cursos criados em 1827. Mesmo não tendo este tema como objeto central, alguns desses autores abordaram o aspecto da inovação ou da apropriação de duas maneiras bem distintas. Schwarcz e Adorno, por exemplo, avaliam que prevaleceu o aspecto de inovação, pois tais cursos teriam sido planejados para nascerem autônomos. José Murilo de Carvalho e Venâncio Filho, por outro lado, veem a sua criação como continuidade do ensino português.

A compreensão da documentação relativa ao tema, composta especialmente por debates parlamentares e por textos normativos da época, não decorre de forma imediata da leitura e reprodução do texto das fontes. A polissemia dos conceitos utilizados tornou imprescindível uma abordagem metodológica para o seu acesso. Nesse sentido, a investigação teve como ponto de partida a proposta teórico-metodológica do historiador Reinhart Koselleck (2006, p.97-118), em especial, a sua reflexão sobre a historicidade dos conceitos. Koselleck chamou atenção para a importância dos significados que os conceitos possuem em um determinado contexto social. Argumentou que em épocas de grandes mudanças políticas as representações sociais dos contemporâneos passam por transformações e os conceitos são ressignificados. Nesse sentido, captar a mudança no entendimento dos conceitos, assim como as suas permanências, é um passo imprescindível na compreensão do momento histórico enfocado. 


\section{A ABERTURA DA ASSEMbleia Constituinte E A APRESENTAÇÃO DO PROJETO DE FUNDAÇÃO DE UNIVERSIDADES E CURSOS JURÍDICOS}

No dia 03 de maio de 1823 ocorreu a instalação solene da Assembleia Geral Constituinte e Legislativa do Império do Brasil. A abertura da Assembleia aconteceu após a ruptura política com Portugal, consolidada em 12 de outubro de 1822 com a aclamação do príncipe regente D. Pedro como imperador constitucional do Brasil. A convocação da Constituinte ocorreu, contudo, em um momento no qual ainda não se pensava em rompimento da união com o Reino Unido, já que o decreto convocatório foi expedido pelo príncipe regente no dia 03 de junho de 1822. Naquela altura, o Brasil buscava autonomia política dentro do Império português que se traduzia na aspiração de um governo próprio na América. ${ }^{2}$ Já em maio de 1823, a instalação da Assembleia representava passo decisivo no processo da consolidação da independência política e da construção do Estado nacional, ao mesmo tempo em que firmava a opção pelo governo constitucional no campo político. Nesse novo contexto, o aspecto constituinte da primeira Assembleia evidencia-se em pelo menos três sentidos concomitantes: ela deveria fundar as bases políticas e institucionais do Estado independente, definir a nacionalidade brasileira e inaugurar juridicamente o regime constitucional.

O Império do Brasil vivia até então um momento de grande incerteza no que diz respeito à organização do Estado e dos direitos civis e políticos. A continuidade da vigência da legislação lusitana no Brasil também era objeto de interrogação. Naquele momento, a Assembleia Constituinte não tinha aprovado ainda a bem conhecida Lei de 20 de outubro de $1823 .{ }^{3}$ Esta declararia em vigor a legislação pela qual se regia o Brasil até 25 de abril de 1821 (ou seja, a legislação portuguesa), as leis promulgadas por D. Pedro daquela data em diante e alguns decretos

2 A esse respeito ver NEVES, 2009a, p.124. Consultar, também, o verbete Independência, de Maria Beatriz Nizza da Silva. SILVA, 1994, p.428-432.

3 Coleção de leis do Império do Brasil - 1823, vol. I. Rio de Janeiro: Imprensa Nacional, 1887, p.07. 
específicos das Cortes Constituintes. Nos anos vinte do século XIX, a revogação do direito estrangeiro não era um imperativo no contexto dos direitos ocidentais, tendo em vista que a soberania nacional ainda não era plenamente identificada com a capacidade do Estado de produzir uma ordem jurídica autônoma e unificada para o território nacional. O próprio Estado português não detinha o monopólio da produção do direito - embora essa tendência já estivesse anunciada a partir da segunda metade do século XVIII — ${ }^{4}$ sendo possível a utilização de fontes doutrinárias, jurisprudenciais e até de leis de outros países. ${ }^{5}$ Manter ou não em vigor o direito português no Brasil certamente exerceria influência no perfil do novo Estado e dos seus primeiros cursos jurídicos.

Por fim, havia indefinição no meio político brasileiro no que diz respeito à natureza do pacto político da unidade soberana em formação, assim como sobre os fundamentos do poder constituinte que remetiam ora à soberania da nação, ora à vontade do imperador aclamado poucos meses antes da instalação da Assembleia. ${ }^{6}$ As discussões na esfera da política sobre as atribuições formais e sobre o real exercício dos poderes legislativo e executivo tinham sido iniciadas já no ano de 1822, com a emancipação política do Brasil. Na abertura dos trabalhos da Assembleia Constituinte, em maio de 1823, D. Pedro I enfatizava no seu pronunciamento a precedência institucional da figura do imperador em relação à Assembleia. A fala do monarca remetia ao pensamento de José Bonifácio de Andrada e Silva, dedicado naquele momento à elaboração dos fundamentos do poder da nova Coroa. ${ }^{7}$ Várias lideranças políticas,

4 Em Portugal, a Lei de 18 ago. 1769, mais conhecida como a Lei da Boa Razão, procurava a centralização do poder político como forma de racionalização do poder e da vida social, direcionando a concentração das fontes do direito para a atividade legislativa do monarca.

5 Hespanha informa que em Portugal, até o final do movimento da codificação no último quartel do século XIX, certas matérias jurídicas ainda eram reguladas pelas "leis das nações cultas e civilizadas da Europa”, como determinava a Lei da Boa Razão. HESPANHA, 2007, p.46, nota 43.

6 Conviviam, após a emancipação política em 1822, várias concepções sobre o pacto político e os poderes dos constituintes. Lúcia Bastos Neves identifica quatro vertentes do constitucionalismo que circulavam no país na época da elaboração da primeira constituição e que tinham posicionamentos diversos sobre essas questões. NEVES, 2009b, p.185-191.

7 Ver, a esse respeito, LYNCH, 2014, p.50-51; 2005, p.623-624. 
tanto na Assembleia Constituinte, como fora dela, contestavam a legitimação da Coroa (Dolhnikoff, 2005, p.44). Andréa Slemian identifica duas posições distintas na Assembleia Constituinte: uma valorizava o papel da Assembleia Legislativa na elaboração no pacto político pois não o considerava constituído; já a outra reconhecia de antemão a autoridade do Imperador que tinha sido aclamado pela nação, ficando preservada a soberania da monarquia (Slemian, 2006, p.85). Lynch relaciona essas mesmas posições em disputa, respectivamente, com os projetos nacionais da "aristocracia rural brasiliense" e dos "coimbrãos" - os antigos servidores da monarquia (Lynch, 2014, p.49). Essas tensões políticas iriam caracterizar todo o período que se estendeu da aclamação pública do imperador até a sua queda em 07 de abril de 1831 -, assim como teriam as suas repercussões no fechamento da Assembleia Constituinte e no processo de criação das escolas de direito em solo nacional.

Os deputados que iniciavam a sua jornada naquele período viviam um tempo marcado pela falta de referências definidas não somente na esfera da normatividade jurídica, como, em especial, no campo político e social. Em suas mãos estavam agora as tarefas de criar e implementar o regime constitucional, assim como o desafio de legislar em um país no qual ainda inexistia uma identidade nacional consolidada, fato que agravava o risco da fragmentação do território nacional. Diretrizes para o futuro tinham que ser formuladas levando em consideração as críticas à realidade política do regime anterior. Ou seja, tarefas inéditas aguardavam as elites políticas no Brasil. Além das transformações provocadas pela Independência política de 1822, os deputados que inauguravam os trabalhos da Assembleia Constituinte tinham consciência de que estavam vivendo uma nova experiência do tempo, singularizada por mudanças na percepção do sentido do passado e pela abertura maior ao futuro. ${ }^{8}$

Para entender o momento histórico vivido pelos constituintes, torna-se necessário captar o encontro peculiar que ocorreu entre as suas experiências e expectativas, ora distantes, ora sobrepostas. Para Tereza

8 O tema do surgimento de uma nova visão do tempo histórico na Modernidade foi trabalhado por KOSELLECK, 2002; 2006, p.305-327. 
Kirschner (2009, p.234), a experiência histórica na qual se inseriam os deputados cruzava, inevitavelmente, tradições do passado com expectativas de novo futuro. A historiadora esclarece que os deputados defendiam o progresso e a civilização, mas sem questionar a escravidão e a distribuição de mercês e privilégios pelo soberano, entre outras práticas antigas.

Enfrentando as suas tarefas políticas inéditas, os deputados e o soberano coordenavam passado e presente de novas maneiras nos seus discursos e ações. Afinal, vivenciava-se um momento político inédito, marcado pelo rompimento político com Portugal e pela permanência de um monarca português no trono. É importante registrar que, além de tensa, a relação entre as tradições herdadas e os projetos de futuro na esfera política e acadêmica não seria estática no decorrer do processo de criação das escolas de direito. Aos poucos, a distância entre essas duas dimensões iria ampliar-se, impulsionada pelos avanços do processo de construção do Estado e da nação.

A relação entre passado e futuro adquiria contornos mais específicos ainda no ambiente dos debates sobre a criação das escolas de direito. Os parlamentares viam-se como construtores de um novo Estado nacional, fato que tinha como pressuposto uma distância das práticas políticas portuguesas. Os seus depoimentos sinalizavam para um futuro não apenas diferente, como melhor, erguido em oposição às suas vivências no âmbito do regime anterior. Ao mesmo tempo, na esfera da cultura, a experiência acadêmica dos deputados na Universidade de Coimbra delimitava os parâmetros das suas intervenções e propostas sobre a concepção dos futuros estabelecimentos de ensino superior no território nacional. Este era um fator que dificultava os questionamentos do modelo de ensino lusitano, assim como as possibilidades de inovações nesse campo.

Em suma, é nesse contexto político, marcado por incertezas e ambiguidades, que seriam abertos os debates parlamentares sobre a criação das universidades e dos cursos jurídicos. Esses debates incorporaram várias das questões importantes que despertavam acirradas polêmicas, como a revisão das representações sobre a relação entre o Brasil e Portugal e 
o desafio de construir a nação e a cidadania; a necessidade de manter a unidade territorial do país, de organizar o Estado e de criar uma oferta permanente de quadros para as funções administrativas e políticas; as funções do ensino superior e jurídico nesse novo tempo que, não obstante, conservava ideias e práticas do Antigo Regime. Enfim, as discussões parlamentares sobre as futuras academias estavam inseridas em uma rede de questões da maior relevância política nos anos vinte do Oitocentos.

A ideia de criação das academias de direito no país surgiu pela primeira vez na sessão de 14 de junho. Na ocasião, José Feliciano Fernandes Pinheiro, constituinte pelo Rio Grande do Sul e doutor em direito pela Universidade de Coimbra, propôs à Assembleia a criação de universidades e cursos jurídicos no território nacional. O deputado embasou a sua proposta no pedido da "mocidade brasileira", matriculada naquele momento na Universidade de Coimbra e que "geme ali debaixo dos mais duros tratamentos e opressão", Decidiu-se pelo envio da proposta à comissão de instrução pública para ser transformada em projeto de lei. No dia 19 de agosto foi lido o curto projeto elaborado pela comissão, transcrito aqui na íntegra por ser este objeto de discussões que se prolongaram até o dia 04 de novembro, ou seja, até poucos dias antes do fechamento da Assembleia que ocorreu no dia 12 de novembro do mesmo ano:

A assembleia geral constituinte e legislativa do Brasil decreta:

1. Haveráõ duas universidades, uma na cidade de São Paulo e outra na de Olinda, nas quaes se ensinaráó todas as sciencias e bellas letras. 2. Estatutos próprios regularáõ o número e ordenados dos professores, a ordem e arranjamento dos estudos.

3. Em tempo competente se designaráõ os fundos precisos a ambos os estabelecimentos.

9 Anais da Assembleia Geral Constituinte e Legislativa do Império do Brasil, 3 vols.. Brasília, Senado Federal, 2003, sessão 14 jun. 1823, p.47. De agora em diante mencionados como Anais da Assembleia Constituinte. 
4. Entretanto haverá desde já um curso jurídico na cidade de S. Paulo para o qual o governo convocará mestres idôneos, os quaes se governaráõ provisoriamente pelos estatutos da universidade de Coimbra, com aquellas alterações e mudanças que elles, em mesa presidida pelo Vice-Reitor, julgarem adequadas ás circunstâncias e luses do século.

5. S.M. o Imperador escolherá dentre os mestres um para servir interinamente de Vice-Reitor. Paço da assembléia, 19 de agosto de 1823. - Martim Francisco Ribeiro de Andrada. - Antonio Rodrigues Velloso de Oliveira. - Belchior Pinheiro de Oliveira. - Antonio Gonçalves Gomide. - Manuel Jacintho Nogueira da Gama.. ${ }^{10}$

Deve ser feito registro, antes da análise dos debates, de alguns traços do perfil dos constituintes que sinalizam para o lugar social da sua fala. O grupo social numericamente mais presente na Assembleia Constituinte e na Assembleia Geral e que se encarregou da tarefa de criar os cursos jurídicos, como parte de um projeto político maior de construção do Estado, era composto por uma pequena elite formada em direito na Universidade de Coimbra no fim do século XVIII e no início do XIX. O grupo desses juristas se caracterizava, para José Murilo de Carvalho, pela homogeneidade ideológica e de treinamento, fornecida pela educação, ocupação e carreira política, fato que forneceu a concepção e as condições de implementação de um determinado modelo de organização política (Carvalho, 2004, p.21). A Assembleia Constituinte era composta por cem deputados, vinte e quatro dos quais participaram das discussões sobre a criação de universidades no Brasil. ${ }^{11}$ Esse grupo específico possuía perfil ainda mais homogêneo em relação ao conjunto da Assembleia. Apenas dois deputados não possuíam grau superior e apenas sete não eram bacharéis em direito. Ademais, desse grupo formado em direito a metade era composta de magistrados. Alberto Venâncio Filho faz menção a autores que qualificam os constituintes como "medíocres" ou "retardados" em função da qualidade das suas intervenções (Venancio

10 Anais da Assembleia Constituinte, sessão 19 ago., p.105.

11 Ver levantamento biográfico deste grupo no Anexo I. 
Filho, 1982, p.14-15). O anacronismo dessa avaliação ressalta mais ainda diante do analfabetismo de aproximadamente $90 \%$ da população na época. A marca distintiva da elite política imperial foi, sem margem de dúvida, a sua excelente instrução.

\section{O PROCESSO DE FORMAÇÃO DA NAÇÃO E AS SUAS REPERCUSSÕES NA CONCEPÇÃO DO ENSINO JURÍDICO}

Poderia se pensar que a emancipação do Brasil em relação ao Portugal fosse produto da consciência nacional ou pelo menos que, após a separação em 1822, esta existisse já amplamente consolidada. No entanto, os Anais da Assembleia Constituinte não confirmam esses pressupostos. Os conceitos relacionados à nação eram objeto de disputa entre os atores políticos e os seus usos pelos parlamentares abrem caminhos para a compreensão das decisões por eles tomadas sobre a concepção dos primeiros cursos jurídicos no Brasil. Vários conceitos em circulação na Assembleia abrigavam sob a mesma grafia significados diversos que sinalizavam para as mudanças, mas também para as permanências, na história política brasileira nas primeiras décadas do Oitocentos. Os diálogos na Assembleia chamam a atenção para o surgimento de um universo mental próprio das elites políticas que se singularizava também pela articulação que fazia do vocabulário disponível para expressar, ou não, pertencimento nacional.

No decorrer dos debates sobre a criação das academias de direito, os conceitos de "pátria", "pátrias", "patriotismo", "paiz" e "nação" não foram empregados de maneira uniforme, evidenciando a complexidade do momento político que se vivenciava. Aliás, era frequente o uso dessas palavras, com significados que podiam ser considerados até opostos: ora a pátria era sinônimo de província ou local de nascimento, ora tinha como referência todo o Império. Dezenas de pronunciamentos fizeram uso dessa terminologia, estando referenciados a seguir apenas alguns deles.

Na primeira discussão do projeto, Francisco Jê Acaiaba de Montesuma e José da Silva Lisboa, ambos constituintes pela Bahia, utilizaram pátria 
e pátrias como sinônimos de províncias; ${ }^{12}$ já Antônio Luis Pereira da Cunha, deputado pelo Rio de Janeiro, identificou o conceito de pátria com o Brasil, afirmando "o Brasil é minha pátria".13 A mesma ambivalência estava presente até quando a palavra "paiz" era veiculada. Para Manuel Jacinto Nogueira da Gama, também deputado pelo Rio de Janeiro, os brasileiros deveriam instruir-se no seu próprio país, e para o representante pernambucano, Almeida e Albuquerque, era "preciso tirar os brasileiros da penosa necessidade de irem mendigar as luzes nos paizes remotos". ${ }^{14}$ Já Silva Lisboa recorreu ao sentido oposto da palavra quando criticou a atitude dos deputados que indicavam as suas províncias para sediar as universidades, "cada um dando preferência segundo o natural affecto ao próprio paiz". ${ }^{15} \mathrm{Ou}$ seja, até o vocábulo país, que parecia ter um significado estabilizado no vocabulário da época, mostrava-se instável.

Os debates evidenciaram que o conceito de pátria circulava no espaço público nos seus dois sentidos, ou seja, com o seu significado anterior e posterior ao período das revoluções do século XVIII. "Pátria" remetia ora a fatos naturais como o lugar de nascimento e o amor à sua terra, sendo utilizada com mais frequência no plural, ora a um sentimento artificial a ser construído em relação ao Estado nacional (Hespanha, 2003).

Pouco tempo antes, por ocasião da reunião das Cortes Gerais Extraordinárias e Constituintes da Nação Portuguesa (1821), parece que o significado oitocentista do conceito de nação, ainda não estava em circulação e nem podia falar-se em uma identidade nacional brasileira. Essa foi a conclusão de István Jancsó e João Paulo Pimenta (2009, p.129-132) após a análise dos manifestos dos deputados das províncias do Brasil - São Paulo e Bahia - nas Cortes. Os deputados, que acusaram o reino de

12 Anais da Assembleia Constituinte, sessão 28 ago., p.135, p.138, respectivamente. Durante as três discussões do projeto, vários outros deputados referiram-se ao vocábulo "pátria" como o lugar de nascimento.

13 Anais da Assembleia Constituinte, sessão 28 ago., p.145.

14 Anais da Assembleia Constituinte, sessão 27 ago., p.136.

15 Anais da Assembleia Constituinte, sessão 18 out.., p.108. 
Portugal pelo rompimento da unidade da nação portuguesa, recorreram também nos seus pronunciamentos às palavras pátria, país e nação. $\mathrm{Na}$ ocasião, pátria seria o lugar de nascimento, não encontrando equivalência com país que seria o Brasil. Já a nação a qual eles mesmos pertenciam seria a portuguesa, sendo que os mesmos sentidos veiculados estavam em circulação no Brasil na época.

As abordagens do conceito de nação na historiografia, conforme apresenta Iara Lis Schiavinatto, foram reorientadas a partir dos anos setenta do século passado. No caso das Américas portuguesa e espanhola, destaca a autora, a ideia de nação passa a ser estudada como um artifício da cultura política e histórica, elaborado por sujeitos sociais com interesses distintos, que a instituem a partir dos movimentos de independência (Schiavinatto, 2009, p.57-60). Esta historiografia procurou afastar-se do padrão oitocentista de escrita sobre a questão, que concebia a nação como um ente natural, pré-discursivo, concatenado à colônia, um verdadeiro sujeito histórico. Esse tipo de interpretação fazia parte dos trabalhos do Instituto Histórico Geográfico Brasileiro (IHGB), fundado em 1839, dos romances históricos, dos artigos de jornais sobre a política e da própria historiografia do Oitocentos.

A existência de várias identidades políticas coletivas no território brasileiro na época da Independência tornou a formação do Estado nacional um fenômeno ainda mais complexo. É comum a uma visão simplista da História equiparar esse fenômeno à emancipação política do Brasil em relação à Portugal, consolidada nos fins de 1822 com a coroação do primeiro imperador. Esse equívoco, mais presente nos estudos do século XIX sobre o surgimento do Estado brasileiro, já foi corrigido pela historiografia brasileira. ${ }^{16} \mathrm{E}$ mais, parece-nos que tem razão Jurandir

16 Para István Jancsó e João Paulo Pimenta, "hoje é assente que não se deve tomar a declaração da vontade de emancipação política como equivalente da constituição do Estado nacional brasileiro.... Informam, ainda, os autores que a historiografia do século XIX orientada em construir uma base de sustentação ao Estado Imperial, contribuiu para o surgimento da ideia de que o rompimento do Brasil com Portugal resultou na fundação tanto do Estado como da nação brasileiros. Nessa tarefa, as obras de IHGB e de Francisco Adolfo de Varnhagen tiveram um lugar de destaque. (JANCSÓ; PIMENTA, 2009, p.132-133). 
Malerba quando argumenta que a tese de que a difusão da concepção de nação é posterior à independência de 1822 e à construção do Estado imperial é mais convincente. ${ }^{17}$

A leitura da documentação produzida pela Assembleia Constituinte também sugere que não havia ainda uma identidade nacional ${ }^{18}$ consolidada no território da ex-colônia. Foi nessas condições que a elite política de 1823 teve de enfrentar, de forma pioneira, a desconcertante tarefa de esboçar uma definição da nacionalidade brasileira — em oposição à portuguesa e, ainda, aos índios, escravos e escravos alforriados que viviam no território do Brasil - estabelecendo critérios diferenciados de cidadania. O desafio consistia em criar uma nação que não ia identificar-se com todo corpo social, por causa principalmente da manutenção do regime escravocrata. Nesse sentido, Jancsó e Pimenta (2009, p.173-174) lembram que não era uma tarefa simples para as elites brasileiras abandonar a tão arraigada identidade portuguesa que sintetizava a sua superioridade em relação à população que não tinha essa condição.

Para a compreensão dos debates sobre a criação dos cursos jurídicos, assim como dos seus estatutos ou currículo, é bastante útil fazer mais uma distinção dentro do tema da Independência. Ou seja, diferenciar o processo de construção do Estado imperial - que começa com a abertura da Assembleia Constituinte (1823) e se encerra com a entrada em vigor do Código Comercial (1850) - da formação de uma nacionalidade brasileira (Malerba, 2006), sem negar as conexões entre ambos.

17 No artigo que se propõe a fazer um balanço da recente historiografia sobre a independência, MALERBA, 2006, trata a emancipação política, a construção do Estado e a formação de uma nacionalidade brasileira como três processos diferentes, com duração diferenciada.

18 Cabe ressaltar que a expressão "identidade nacional" está sento utilizada aqui como categoria de análise e não como conceito extraído das fontes da época. A diferença entre esses dois tipos de conceitos é trabalhada por Koselleck para quem o historiador, no seu ofício, se move em dois planos: ou recorre aos conceitos tradicionais da linguagem das fontes ou utiliza conceitos definidos posteriormente, como categorias científicas. KOSELLECK, 2006, p.305. A expressão "identidade nacional" aqui está sendo utilizada no sentido já definido por Carvalho. Para ele, o conceito de nação remete à formação de identidades coletivas entre as quais a principal é a nacional, e ao sentimento de comunidade entre os habitantes de um Estado; a identidade nacional se constitui no diálogo com as identidades subnacionais, tais como as étnicas, regionais, religiosas. CARVALHO, 2007, p.09-14. 
A observação de Jancsó e Pimenta (2009, p.132-136) é novamente esclarecedora. Depois de constatar que as pesquisas contemporâneas privilegiavam a formação do Estado, pressupondo com isso que estavam realizando também estudos sobre a nação, optaram os autores por dar ênfase à construção da identidade nacional, reconhecendo que a investigação é mais difícil por lidar também com dimensões subjetivas da realidade, como percepções, sentimentos e emoção.

Uma vez colocados esses pressupostos, cabe aprofundar a análise do surgimento dos primeiros cursos jurídicos a partir deles. É certa a afirmação corrente de que o projeto de criação dessas escolas estaria inserido nos processos de constituição do Estado imperial e da nação? Ademais, as premissas aqui expostas oferecem subsídios adequados para explicar as concepções diferenciadas dos deputados da Assembleia Constituinte e da Assembleia Geral no tocante ao projeto das academias de direito.

Pode-se observar nos debates da Assembleia Constituinte como os momentos de profundas mudanças políticas pelas quais passava o Brasil a partir de 1808 se traduziram em modificações no vocabulário utilizado pelos parlamentares. Conceitos antigos renovavam os seus sentidos e novas palavras entravam em uso. Ao mesmo tempo, antigos e novos significados coexistiam em alguns conceitos e a escolha do seu uso era influenciada, com frequência, pelas intenções dos interlocutores no debate político. Quando o debate sobre o ensino superior e jurídico trazia alguma referência negativa a Portugal, em geral catalisava sentidos mais unitários e emotivos dos conceitos de pátria, país e nação, equiparando-os ao Império do Brasil. As falas dos deputados Fernandes Pinheiro, Antônio Luis Pereira da Cunha, representante do Rio de Janeiro, e do mineiro Cândido José de Araújo Viana ilustram bem esse uso diferenciado do vocabulário nas circunstâncias em que se veiculavam posicionamentos críticos à antiga metrópole, em especial à esfera da política metropolitana. Esses discursos, decorrência das ações inéditas dos atores políticos, contribuíram para a criação de um novo vocabulário político.

Já na primeira discussão, Fernandes Pinheiro tinha dirigido duras palavras à política educacional monopolizadora do "governo velho" da qual 
resultou a ida para Coimbra dos estudantes brasileiros que foram sujeitos a "privações no meio de um povo mal affeiçoado". ${ }^{19} \mathrm{Na}$ mesma ocasião, o deputado Pereira da Cunha, pronunciando-se sobre o mesmo tema, afirmou ter sido "erro grosseiro do antigo sistema com o qual pretendia a política portuguesa conservar-nos na escravidão e na dependência”. ${ }^{20}$ Parece razoável a crítica dos membros da Assembleia dirigida à política de proibição de instalação de cursos superiores no território da antiga colônia, posição modificada apenas com a transferência da corte para o Rio de Janeiro, em 1808. O que chama a atenção, no entanto, é o vocabulário utilizado na sua formulação, em tom exagerado e panfletário, que destoava diante do apreço que aquele grupo social demonstrava, nas sessões dessa mesma Assembleia, pela cultura portuguesa, e que seria projetado na concepção do ensino jurídico dos constituintes.

A fala de Araújo Vianna também chama atenção pelo modo como se refere ao reino português antes e depois da independência. Na visão do deputado, Portugal passou a ser "um reino estrangeiro e inimigo" apenas após a ruptura política de 1822. Disse ele: “Quem negará o grande bem de poder a nossa mocidade instruir-se no seu próprio paiz quando antigamente só o podia fazer indo a Portugal, que de mais a mais é hoje, depois de feita a separação, um reino estrangeiro e inimigo?". ${ }^{21}$

Ao mesmo tempo, faz-se também registro do uso frequente na Assembleia da expressão “jugo lusitano" para denunciar os abusos do governo português. Aliás, nessas falas percebe-se uma proximidade entre as palavras usadas, tais como "dependência", "escravidão", "privação", "inimigo", "governo velho", "jugo lusitano", todas elas indicando situações de exploração colonial e denunciando o caráter opressivo dos governos absolutos. No seu sentido mais geral, esses vocábulos remetiam à negação da liberdade que o movimento constitucionalista pretendia recuperar. Para Lúcia Maria Neves (2003, p.125-126), essas palavras e conceitos, já amplamente utilizados antes mesmo do início das sessões

19 Anais da Assembleia Constituinte, sessão 27 ago., p.134.

20 Anais da Assembleia Constituinte, sessão 28 ago., p.145.

21 Anais da Assembleia Constituinte, sessão 28 ago., p.149. 
da Constituinte brasileira nos jornais, panfletos e periódicos, sintetizavam críticas elaboradas contra o regime anterior à regeneração vintista. Entretanto, lembra a historiadora, o uso dessas expressões não era idêntico no Brasil e em Portugal: aqui o "despotismo" ao qual as palavras estavam associadas também era atribuído à atuação das próprias Cortes de Lisboa, a partir de 1822.

A relação entre os discursos e os fatos, entre a linguagem e a vida, pode ser ainda mais complexa nos momentos de crises e profundas mudanças históricas. Embora esse novo vínculo dos contemporâneos com o passado colonial tivesse se transformado em representação dominante na esfera das relações políticas entre Brasil e Portugal, no âmbito da cultura parece que ele não tinha criado raízes firmes. Os fatos podiam ser mais persistentes que os discursos, mesmo quando esses eram peças fundadoras da constituição de um novo Estado. A concepção dos deputados sobre os parâmetros da formação jurídica, contidos, em especial, nos estatutos dos cursos jurídicos, oferecem elementos para a formulação dessa hipótese. Antes disso, faz-se registro da forte influência da cultura portuguesa no campo do direito: o espírito antilusitano pós-independência não atingiu o sistema legal português como um todo. A legislação da antiga metrópole foi adotada, provisoriamente até a criação dos Códigos modernos - que somente seria completada em 1916 com a aprovação do Código Civil —, ${ }^{22}$ como o direito pátrio vigente, ao lado do direito oficial elaborado após os acontecimentos de 1822. A Assembleia Constituinte fez uma escolha política no sentido de recepcionar o direito português no país, estando ciente que se tratava de uma legislação elaborada no Antigo Regime pelos monarcas portugueses e que refletia as relações sociais e de poder existentes naquela época.

As raízes das permanências da cultura portuguesa no Brasil poderão ser procuradas na consolidação tardia da identidade nacional em relação à independência política de 1822 e nas especificidades do processo de independência. Para Pedreira (2006, p.60-61), a atitude crítica de

22 Sobre as razões da demora da elaboração do Código Civil, ver GRINBERG, 2001, que destaca a escravidão como um fator impeditivo. 
Sérgio Buarque de Holanda e Maria Odila da Silva Dias foi decisiva para dissociar a emancipação política da formação de um sentimento nacional. De acordo com as pesquisas da historiadora Maria Odila, a separação entre Portugal e Brasil resultou de dissidências internas de Portugal (e não de uma guerra de independência), não podendo ser colocados em segundo plano nessa explicação o "enraizamento dos interesses portugueses" e "o processo de interiorização da metrópole no Centro-Sul da Colônia”. Como já foi assinalado, existe certo consenso na historiografia contemporânea sobre o assunto.

Chama a atenção no curto projeto de lei em análise o artigo $4^{\circ}$, que estabelece a adoção provisória dos estatutos da Universidade de Coimbra de 1772 nas futuras academias brasileiras de direito. Para o deputado baiano Luis José de Carvalho e Mello, Portugal carecia de todas as luzes até o advento daqueles "excelentes estatutos". ${ }^{23}$ A adoção desta regulamentação no Brasil não foi problematizada nas sessões seguintes e nem sequer foi discutida a matéria, sendo aprovado o artigo, nesta parte, na sua redação original.

O discurso hostil produzido pelas elites que promoveram a independência condenando o passado colonial não atingia, nas circunstâncias, a política da "luminosa reforma" ${ }^{4}$ no âmbito do ensino universitário. Esse discurso, se não examinado criticamente à luz de outros discursos da época e diante dos resultados de recentes pesquisas, pode tornar imprecisa a historiografia sobre o período. Parte da literatura consultada sobre a criação dos cursos jurídicos afirma que a emergência do Estado nacional demandava a burocratização do aparelho estatal, assim como uma formação cultural autônoma. Sobre esse último tópico, Lilia Schwarcz (1993, p.141-142) constata que as academias de direito se propunham a formar elites independentes dos laços culturais que prendiam o país à metrópole europeia, capacitadas para inventar novos modelos para a nação. Nos Anais da Assembleia Constituinte não foram encontrados registros dessa intenção das elites políticas, mas apenas algumas falas

23 Anais da Assembleia Constituinte, sessão 27 ago., p.133.

24 Anais da Assembleia Constituinte, sessão 27 ago., p.133. 
referentes ao contexto político geralmente veiculadas a expressões como "romper os laços de dependência" com a antiga metrópole. Será que não estamos diante de fragmentos do discurso oficial dos deputados que objetivava justificar a independência política do Brasil? Parece que na Assembleia de 1823 a ideia de formação da cultura brasileira ainda não tinha espaço. Alguns discursos nesse sentido iriam aparecer nos debates da Assembleia Geral, a partir de 1826. Os pronunciamentos críticos ao antigo governo foram rapidamente esquecidos quando confrontados com uma decisão concreta, que dizia respeito à adoção dos estatutos da Universidade de Coimbra que regulavam no detalhe a formação jurídica. Cabe ressaltar que os estatutos, escritos na época pombalina e em parte modificados posteriormente, possuíam cerca de 300 páginas, abarcando todas as orientações pedagógicas e regulamentações sobre o ensino do direito. ${ }^{25} \mathrm{O}$ fato também explica o porquê do projeto de lei ser tão curto, além de não deixar nenhuma dúvida quando a sua concepção lusitana de ensino jurídico a ser implantada no Brasil. A decisão sobre os estatutos é um exemplo ilustrativo do universo mental dos deputados que sinalizava para o peso do passado vivenciado no ambiente educacional de Coimbra. Constatou-se, desse modo, que em função do contexto vivenciado logo após a emancipação política, os membros da Assembleia Constituinte e Legislativa não projetaram os primeiros cursos jurídicos como mecanismos de consolidação do sentimento nacional.

\section{AS FUNÇÕES DOS CURSOS JURÍDICOS NO CONTEXTO DE CONSTRUÇÃo DO ESTADO}

Se os deputados em 1823 não pensavam ainda vincular as academias de direito ao processo de fortalecimento da identidade nacional, qual seria a relação do projeto com a formação do Estado? As discussões sobre as funções do ensino superior e o perfil profissional dos bacharéis

25 Trata-se do segundo volume dos Estatutos da Universidade de Coimbra, referente à Faculdade de Direito. Estatutos da Universidade de Coimbra (1772). Coimbra: Imprensa da Universidade, 1972. 
evidenciam os modos pelos quais a elite política planejava inserir as academias de direito no processo de construção do Estado Imperial.

Vários deputados discutiam as funções educacionais das universidades com termos bastante genéricos, dos quais é difícil extrair alguma pluralidade ou divergência nas linhas de pensamento. Ao contrário, os pronunciamentos convergiam para sentidos bastante próximos: a difusão das luzes levaria à prosperidade do Império e à aceleração do seu processo civilizacional. A sessão do dia 27 de agosto foi rica em discursos que atribuíam à instrução formal esses resultados. Fernandes Pinheiro não tinha dúvida: a aprovação do projeto em pauta levaria à "diffusão de luzes" e, portanto, à "rápida civilisação" e a "melhores costumes". ${ }^{26}$ Silva Lisboa, na mesma sessão, também equiparou a instrução formal à civilização. Para Antônio Gonçalves Gomide, deputado por Minas Gerais, todas as virtudes cívicas e morais das nações se desenvolveram em razão das luzes e na falta dessas era a "barbárie" que prosperava. A educação formal, de acordo com o mesmo parlamentar, era também veículo de aprimoramento moral do indivíduo:

Nada de bom e de grande, senão por acaso se póde esperar da índole, instincto, propensão natural, boas intenções, etc., faltando conhecimentos; ...Todos os actos humanos são decisões de vontade, e esta se decide depois de combinações, reflexões, e raciocínios seguidos; como se poderáõ pois esperar acções illustres e virtuosas, deduzidas de juízos falsos, e de princípios errados?. ${ }^{27}$

É importante registrar que essas concepções pedagógicas sobre a educação foram compartilhadas por todos os deputados que fizeram uso da palavra e que as premissas nelas contidas, próprias do Iluminismo, eram amplamente difundidas entre as elites dos dois lados do Atlântico.

Também não houve divergências no que tange ao perfil profissional dos futuros bacharéis. O destino deles estaria já selado - transformar-se

26 Anais da Assembleia Constituinte, sessão 27 ago., p.134.

27 Anais da Assembleia Constituinte, sessão 27 ago., p.136. 
em servidores do Estado. Quais são as origens dessa atitude das elites políticas que direcionava a trajetória profissional dos bacharéis, egressos em princípio de qualquer curso superior, para as funções do Estado? Desde o início da época moderna, a evolução dos aparelhos administrativos do Estado e da Igreja tinha ampliado a demanda por funcionários que começaram a ser selecionados no grupo dos letrados. $\mathrm{O}$ fenômeno era comum ao continente europeu: os serviços públicos, junto com as profissões liberais e o clero eram as saídas naturais para os universitários (Charle; Verger, 1996). No mundo atlântico, a prática de vincular a formação universitária às carreiras no Estado era muito difundida, sendo que os representantes da nação reunidos em 1823 deram continuidade ao modelo luso de formação e ocupação dos funcionários.

Quando os parlamentares faziam as suas projeções sobre o futuro profissional dos bacharéis, eles já levavam em consideração a sua vivência cotidiana na qual os cargos políticos e administrativos do recém-criado Estado estavam sendo ocupados principalmente por homens formados em Coimbra nos fins do século anterior. Segundo o registro do deputado Carvalho e Mello, é da Universidade de Coimbra que "vieram os que atualmente exercem os empregos mais distintos do Estado". ${ }^{28}$ E também, a própria Assembleia era composta quase na sua totalidade por homens com estudos superiores. As fontes documentais e os quadros estatísticos apresentados por José Murilo de Carvalho (2004) confirmam a ideia de que os bacharéis formados em direito na Universidade de Coimbra tiveram papel de destaque na construção do Estado nacional. Nesse contexto, o mesmo historiador do Império trata a educação superior e jurídica como poderoso elemento de unificação ideológica da elite imperial.

Logo nas suas primeiras reuniões, a Assembleia reconheceu a necessidade e a urgência de instrução pública em universidades ou colégios, sendo que os deputados se referiam inicialmente ao projeto de lei em análise como o de "fundação de duas universidades". Contudo, a verdadeira urgência que se revelava no decorrer dos debates e que já estava

28 Anais da Assembleia Constituinte, sessão 27 ago., p.133. 
configurada no próprio projeto apresentado pela comissão de instrução pública dizia respeito apenas à abertura de cursos jurídicos. A história subsequente do ensino superior confirmaria a mesma intenção: seriam necessários apenas quatro anos para a abertura de cursos jurídicos no país e mais de um século para a inauguração de universidades. ${ }^{29}$

A urgência na instalação dos cursos jurídicos no Brasil decorreu, em grande medida, da necessidade de reprodução dos quadros da administração estatal, agora no território nacional. Os deputados atribuíram essa função a todos os cursos superiores. No entanto, a votação final não deixou margem para dúvidas: é dos cursos jurídicos que provinham os cidadãos hábeis para os empregos do Estado. A história das profissões jurídicas colabora para o entendimento da escolha da Assembleia: desde o seu surgimento, as faculdades de direito se tornaram celeiros de servidores fiéis aos poderes políticos existentes vinculados a reinos, igrejas, cidades independentes, Estados, sendo que um número inexpressivo de juristas se desviou dessa função social. Magistratura, diplomacia, administração estatal, cargos políticos e advocacia seriam as ocupações profissionais selecionadas para os bacharéis em direito. Como se sabe, no campo da educação, em contraste com os países de colonização espanhola, a especificidade do Brasil remetia à inexistência de estabelecimentos de ensino superior até 1808. A história institucional desses estabelecimentos começou no Brasil com a chegada da corte, à qual seguiu-se a inauguração de vários cursos superiores. Apesar disso, as escolas criadas explicitamente para a formação das elites políticas somente surgiram após a independência, tratando-se das escolas de direito (Carvalho, 2004, p.74).

Foi bem coerente com as demandas políticas da formação do Estado a célere atuação dos deputados em planejar a formação de bacharéis,

29 As duas escolas de direito foram criadas pela Lei de 11 ago. 1827; o ano do efetivo início das suas atividades foi 1828. As aulas começaram em 01 mar. 1828, em São Paulo, e em 15 maio 1828, em Olinda. Já as universidades surgiram no país no século seguinte. A Universidade do Paraná foi fundada 1912, a universidade do Rio de Janeiro em 1920 e a Universidade de Minas Gerais em 1927. Entretanto, de acordo com critérios acadêmicos, a primeira universidade no Brasil seria a Universidade de São Paulo, inaugurada em 25 jan. 1934. 
no território nacional, para os altos cargos da administração pública e para a vida política. Entretanto, proporcionar uma formação dentro dos parâmetros de uma cultura jurídica própria representava um desafio maior, tendo em vista que os deputados compartilhavam até pouco tempo atrás a mesma cultura política e jurídica, e a mesma identidade com os portugueses. Nesse encontro entre as experiências e as expectativas que ocorreu na discussão do projeto das academias de direito, as permanências tiveram espaço predominante. E como não foram feitos esforços em criar uma legislação e um modelo de ensino jurídico que correspondessem às especificidades do Brasil após a emancipação política de 1822, chegou-se à conclusão que na Assembleia Constituinte não existiu um contexto propício para que as elites políticas buscassem formação autônoma da concepção portuguesa do direito e do seu ensino. A lei aprovada pela Constituinte remetia para uma reprodução deliberada do padrão lusitano de faculdade de direito vivenciado na Universidade de Coimbra. Dessa forma, o modelo de ensino jurídico consagrado na lei não foi pensado como um mecanismo de fortalecimento da identidade nacional.

O projeto de lei foi aprovado em 04 de novembro de 1823, prevendo a instalação de dois cursos jurídicos: um na cidade de São Paulo e outro em Olinda. Entretanto, a dissolução da Assembleia Constituinte no dia 12 de novembro interrompeu o trâmite do projeto. Embora já aprovado, não chegou a ser convertido em lei e, consequentemente, não foi executado. Entre os diversos fatores que provocaram o fechamento da Assembleia destaca-se o agravamento da disputa com o monarca pela liderança na representação da soberania nacional. A Assembleia, aos poucos, tinha-se tornado a principal detentora da soberania afirmando o seu papel constituinte no pacto social, o que repercutia na progressiva perda dos poderes do imperador como, por exemplo, o poder de veto da legislação originada no Parlamento. Nesse contexto, no dia 12 de novembro o imperador inverteu a balança e quis dar provas do seu poder preexistente e superior. De imediato, o monarca criou o Conselho de Estado que foi encarregado da elaboração de um novo projeto de Constituição. Também, deu ordens para o aprisionamento de vários 
deputados e para a expatriação de alguns deles, entre os quais constaram nomes de políticos que participaram ativamente nos debates sobre a criação dos cursos de direito. ${ }^{30}$

A primeira Constituição do Brasil entrou em vigor no dia 25 de março de 1824, com o aval das câmaras municipais ${ }^{31}$ e sem a convocação de uma nova Constituinte. De acordo com Lucia Bastos Neves (2009b, p.193-194), esse fato dividiu as opiniões dos contemporâneos. Para alguns, a outorga da Constituição significou que o direito do rei era anterior à Constituição, sem se fundamentar nessa, o que iria de encontro aos postulados do constitucionalismo moderno. Já para outros, a anuência das Câmaras Municipais substituía a aprovação do projeto pela Assembleia Constituinte, ficando assim preservada a perspectiva moderna de constituição. Uma das inovações importantes da Carta de 1824 no contexto da política imperial foi a criação do poder moderador, delegado privativamente ao imperador. ${ }^{32}$ Assim, no dia 25 de março, por meio da constitucionalização das prerrogativas de dissolução da Câmara e do direito de veto, o imperador reafirmou a sua primazia no pacto político. É importante ressaltar que o texto constitucional definiu o âmbito desses poderes de forma que a dissolução da Câmara não fosse confundida com fechamento arbitrário da Casa e o direito de veto não fosse o absoluto, mas o relativo. ${ }^{33}$ A partir de então o monarca e a Assembleia se tornariam os representantes legítimos da nação - uma solução de compromisso que certamente não colocava termo às disputas entre os poderes políticos. Registra-se, por fim, que os esforços dos constituintes no sentido de fundar o ensino jurídico nacional não foram em vão: em

30 Martim Francisco Ribeiro de Andrada e Francisco Jê Acaiaba de Montesuma fizeram parte do grupo dos deputados presos e exilados. RODRIGUES, José Honório. Atas do Conselho de Estado. Segundo Conselho de Estado, 1823-1834, p.03. Disponível em: www.senado.gov. br; Acesso em: 06 dez. 2016.

31 Com exceção das Câmaras de Itu e de Recife.

32 Constituições brasileiras. Brasília: Senado Federal, 2001. Constituição Politica do Imperio do Brazil (25 mar. 1824), art. 98. Disponível em: www.planalto.gov.br; Acesso em: 01 dez. 2016.

33 Constituição Politica do Imperio do Brazil (25 mar. 1824), artigos 62, 65 e 101, incisos III e V. Disponível em: www.planalto.gov.br; Acesso em: 01 dez. 2016. 
1826, a Assembleia Geral Legislativa retomaria a discussão, tendo como ponto de partida o texto aprovado pela Assembleia Constituinte.

\section{A ABERTURA DA ASSEMBLEIA GERAL NO CONTEXTO DAS MUDANÇAS NO CENÁRIO POLÍTICO}

No dia 06 de maio de 1826 foi instalada, em sessão solene, a primeira legislatura da Assembleia Geral Legislativa. Logo após o início dos trabalhos da Assembleia Geral, na sessão da Câmara dos Deputados do dia 12 de maio de 1826, a questão da criação de universidades e cursos jurídicos foi trazida para o debate. Lúcio Soares Teixeira de Gouvêa, representante por Minas Gerais, e deputado em 1823, propôs à Câmara a retomada do assunto com base no projeto de lei já aprovado pela Constituinte. A memória desse projeto mantinha-se viva entre as elites políticas reunidas na primeira legislatura. Tinham-se passado apenas três anos. Não obstante, esse curto período, do ponto de vista político, foi palco de acontecimentos relevantes e de intensas transformações. ${ }^{34}$

A Câmara dos Deputados iniciou os seus trabalhos em clima de desconfiança em relação ao espírito constitucional e patriótico do imperador e de críticas ao seu poder considerado excessivo. O monarca conseguiria repartir o seu poder com a Assembleia Geral no novo contexto constitucional? Afinal, desde a dissolução da Constituinte, D. Pedro I concentrava toda a atividade legiferante em suas mãos, exercendo-a com o auxílio do Conselho de Estado. Em 1826, com a reabertura da Assembleia, a disputa em torno da representação da nação seria retomada ${ }^{35}$ e agravar-se-ia progressivamente até a queda do imperador, em 07 de abril de 1831. A falta de experiência do modo de funcionamento do regime constitucional em 1823 aos poucos estava sendo substituída por

34 Ver, nesse sentido, RIBEIRO; PEREIRA (2009, p.154-162), que fizeram uma revisão da tradicional datação e avaliação dos acontecimentos do Primeiro Reinado, identificando como um momento político específico o período entre 1826, iniciado com a abertura da Assembleia Geral, e 1831 que corresponde à queda do imperador.

35 A Constituição de 1824 tinha deixado brechas no que dizia respeito ao exercício dos poderes políticos, permitindo dessa forma várias interpretações. LYNCH, 2005. 
alguns aprendizados sobre os desafios na implementação desse regime. A Constituição outorgada tinha mudado o clima político do Primeiro Reinado, intensificando as animosidades entre as forças políticas da oposição e o imperador e seu ministério. Vários membros da elite política estavam interpretando o fechamento da Assembleia Constituinte e as decisões posteriores de D. Pedro I - a expatriação de parlamentares, a criação do Conselho de Estado, a outorga da Constituição - como manifestações de despotismo no seu governo.

Um outro fato ocorrido pouco tempo antes da instalação da Assembleia Geral intensificou a oposição ao imperador. A morte de D. João VI, em 10 de março de 1826, criou um quadro de possibilidades para a sucessão ao trono português, que gerou incertezas nos dois reinos. Mesmo após a solução do problema com a abdicação ao trono em favor da sua filha D. Maria da Glória, o envolvimento de D. Pedro I com as questões da sucessão iria perdurar até o fim do Primeiro Reinado, contribuindo mais ainda para o seu desgaste. Ademais, o problema das finanças do novo Império, enfraquecidas por gastos militares e tratados desvantajosos, interferia na Assembleia Geral. Em conexão com esses fatos, observou-se no curto período aqui abordado um avanço dos discursos patrióticos que teria repercussões nos debates sobre as academias de direito.

As mudanças no cenário político ressoavam nos debates sobre os cursos jurídicos da Assembleia Geral, influenciando os pronunciamentos e as decisões dos parlamentares sobre as futuras escolas. Dessa forma, impulsionaram o surgimento de uma nova relação dos contemporâneos com o passado colonial, provocando mudanças nas memórias dos deputados no que tange à sua experiência acadêmica. Assim, em 1826, um grupo de deputados começou a formular fortes críticas ao clima intelectual e político no reino de Portugal e à estrutura do ensino da Universidade de Coimbra. O outro grupo se manteve mais fiel à visão sobre a concepção do ensino jurídico que predominou na Assembleia Constituinte. O valor histórico do passado estava em disputa e transformação.

Dessa forma, entre 1823 e 1826, a avaliação por parte dos parlamentares do mesmo fenômeno histórico - o ensino superior em Coimbra estava mudando. O grupo que se encarregou da tarefa de criar as escolas 
de direito era o mesmo. Nas suas obras, José Murilo de Carvalho (2004) e Kenneth Maxwell (1999) trataram como um grupo a elite política do Primeiro Reinado. Para Carvalho, a formação universitária/jurídica em Coimbra e o exercício profissional dela decorrente eram fatores que atribuíram homogeneidade ao grupo. A lista dos membros das duas assembleias evidentemente não era idêntica na sua totalidade, embora vários constituintes tenham sido novamente eleitos para a primeira legislatura. Também tinha surgido um novo subgrupo na Câmara, composto por bacharéis formados no período que antecedeu a emancipação política do Brasil e que tinha vivenciado a tensão crescente nas relações entre os portugueses e os luso-brasileiros. Bernardo Pereira de Vasconcellos, deputado por Minas Gerais, fazia parte desse grupo, enfrentando um clima não amigável para os estudantes da América portuguesa. Alguns dos seus pronunciamentos em 1826 revelam que esse fato aguçou o seu espírito crítico em relação à metrópole e fortaleceu a sua visão da nacionalidade brasileira. ${ }^{36}$ Desta vez, na Assembleia Geral, a elite política teria condições de imprimir um padrão nacional de ensino jurídico à lei que iria fundar as academias de direito?

\section{CRÍticas AO ENSINO do DiREITO NA UNIVERSIDAdE DE COIMbRA E AS NOVAS PROPOSTAS}

Incumbida de organizar um projeto de lei sobre as escolas de direito, a Comissão de Instrução Pública apresentou a sua proposta no dia 05 de julho de 1826. O projeto previa em seu eixo estrutural a abertura de um curso jurídico na cidade de Rio de Janeiro, com oito cadeiras, regido provisoriamente pelos Estatutos da Universidade de Coimbra (1772), até a elaboração dos estatutos próprios pela congregação dos futuros lentes. Da análise da documentação ${ }^{37}$ percebe-se que, a partir de 1826,

36 Anais da Câmara dos Deputados (1826-1827). Brasília: Senado Federal, 1996, sessão 07 ago., p.64-65.

37 Os três debates regimentalmente previstos ocorreram entre os dias 01 ago. e 31 ago. 1826. Anais da Câmara dos Deputados, de sessão de 01 ago. até sessão 31 ago.. 
a nova leitura dos deputados sobre o passado colonial se constituía não somente em representação dominante na esfera das relações políticas entre Brasil e Portugal, mas começava a atingir discursivamente o âmbito da cultura. A estrutura do ensino superior, assim como algumas tendências da formação jurídica lusitana, foram objeto de agudas críticas. A Câmara, por exemplo, questionou a adoção dos estatutos da Universidade de Coimbra nos cursos jurídicos brasileiros.

O projeto de lei estabelecia que os cursos deveriam ser regidos provisoriamente, e na parte considerada aplicável, pelos estatutos da Universidade de Coimbra, reproduzindo a regra da lei aprovada pela Assembleia Constituinte. José Clemente Pereira, deputado por Rio de Janeiro, propôs a emenda que visava substituir aqueles estatutos pelos de visconde da Cachoeira, ${ }^{38}$ elaborados em 1825 para o curso jurídico no Rio de Janeiro, criado pelo imperador, que não chegou a funcionar. ${ }^{39} \mathrm{O}$ deputado por Pernambuco, Hollanda Cavalcanti, pediu a palavra para discordar dessa emenda com o argumento de que seria mais correto adotar os da Universidade de Coimbra. Afinal, acrescentou o deputado, os estatutos do visconde da Cachoeira foram "tirados dos desta mesma universidade" ${ }^{40}$ Em seguida, dois deputados de peso se manifestaram, cujo pensamento convenceu o auditório e encerrou de forma rápida a discussão. Lino Coutinho e Vasconcellos apoiaram a emenda de Clemente Pereira com argumentos que merecem ser transcritos na íntegra. Coutinho afirmou o seguinte: "Eu sou da opinião do Sr. Clemente Pereira, e que fujamos de tudo quanto é estrangeiro, visto que existem os estatutos feitos por um cidadão brazileiro, que muito é que nós lancemos mão de uma obra nacional?". ${ }^{11}$ Vasconcellos acrescentou: “Tambem voto pela emenda do Sr. Clemente Pereira, para que se regule este curso pelos

38 Estatutos do Visconde da Cachoeira. In: Collecção das Leis do Imperio do Brazil de 1827. Parte Primeira. Rio de Janeiro: Typographia Nacional, 1878, p.11, p.18. O autor dos estatutos é o baiano Luis José de Carvalho e Melo que foi magistrado, deputado constituinte e senador eleito para a primeira legislatura.

39 O curso foi criado pelo Decreto 09 jan. 1825.

40 Anais da Câmara dos Deputados, sessão 09 ago., p.85.

41 Anais da Câmara dos Deputados, sessão 09 ago., p.85. 
estatutos do visconde, porque são melhores do que os de Coimbra, que sempre são estrangeiros". ${ }^{42}$

A fala dos dois deputados resumiu o argumento que prevaleceu: a obra brasileira é melhor porque é "nacional". A Câmara dos Deputados fez uma opção diferente da dos parlamentares de 1823, que não problematizaram a adoção dos estatutos portugueses. Naquela ocasião, a Assembleia Constituinte estava direcionando esforços para a edificação de uma nova ordem política embasada no constitucionalismo moderno, e os deputados ainda não tinham relacionado o processo de emancipação política à autonomização cultural. Porém, as escolhas das duas assembleias, no que tange ao seu conteúdo, não eram distintas, tendo em vista que, de acordo com os mesmos deputados, os estatutos de visconde da Cachoeira eram similares aos da Universidade de Coimbra. ${ }^{43}$

A partir de 1826, um grupo de deputados, por razões variadas e por meio de diversas estratégias, começou a questionar a adoção do modelo português de ensino do direito. Refletir sobre esses questionamentos requer, além de atenção com os acontecimentos na esfera da política já expostos, a compreensão do processo de constituição da nação desencadeado com o rompimento com Portugal. No início do trabalho já foi dado destaque ao pressuposto teórico relativo à inexistência da nação brasileira até a independência de 1822. Da mesma forma, para a historiadora Lúcia Bastos Neves (2009a, p.129) a concepção moderna de nação começa a circular apenas no fim de 1822, com a aclamação do príncipe regente como imperador, veiculando a ideia de separação e distinção de um povo em relação ao outro. A autora recorre a uma diferenciação entre dois significados do conceito de nação - o político e o cultural -, em condições de clarear alguns processos em curso no novo Império e nos debates da Assembleia. De acordo com o estudo, o conceito na época da independência apresentava apenas o seu sentido político, ou seja, ser um Estado soberano, e não ainda o cultural,

42 Anais da Câmara dos Deputados, sessão 09 ago., p.85-86.

43 A nossa análise dos estatutos do visconde da Cachoeira confirma a avaliação dos deputados sobre as fortes semelhanças com os estatutos da Universidade de Coimbra (1772). 
identificado com a existência de uma comunidade dotada de identidades singulares.

É importante registrar que na análise do projeto de criação de universidades e cursos jurídicos em 1823 já se observava a presença da ideia política de nação, em especial nas falas sobre a necessidade de rompimento dos vínculos de dependência com Portugal. Em 1826, nos debates sobre os cursos jurídicos, o significado cultural da nação se fez presente atribuindo às intervenções de Coutinho e Vasconcellos acima referidas tom paradigmático. Naquele momento, o adjetivo "nacional" começou a ser utilizado como o oposto ao de "estrangeiro", sendo o último termo empregado quase exclusivamente para adjetivar o reino de Portugal, visto pelos parlamentares como o maior obstáculo para a constituição da nova nação. Ou melhor, esse reino passava a configurar a alteridade na qual poderia refletir-se a identidade nacional. Na Câmara, a necessidade de distanciar-se das concepções e dos valores jurídicos lusitanos foi transformada em tarefa constantemente exercitada pelos deputados, de forma discursiva e, às vezes, com resultados efetivos. Afinal, normas, instituições, valores, símbolos originados em solo brasileiro davam visibilidade à existência da nova nação e ajudavam na construção do sentimento de comunidade entre os seus habitantes.

Com a mesma chave de leitura pode ser entendida a decisão da Assembleia Constituinte, mantida pela Câmara dos Deputados e pelo Senado, ${ }^{44}$ de serem criadas duas escolas de direito no país, nas regiões Sul e Norte. Esta fazia parte de um projeto político que procurava integrar as diferentes regiões do país, por meio de um projeto de ensino jurídico. O uso das expressões "região Sul" e "região Norte", que não eram de natureza apenas geográfica, remetia às preocupações dos parlamentares com a unidade territorial. O debate sobre a localização dos cursos refletiu também as tensões políticas entre o imperador e a Câmara dos Deputados. A maioria não aceitou as orientações do imperador de ser a

44 Faz-se registro de que o Senado, em face da necessidade da urgente aprovação do projeto, não modificou o texto que lhe foi submetido à avaliação. A mesma atitude tomou também o imperador. Anais do Senado Federal (1826-1835). Brasília: Senado Federal, 1996. 
capital a sede de um curso, ${ }^{45}$ o que levou ao seu desgaste no âmbito do Parlamento e ao fortalecimento dos interesses das províncias. A votação sobre a localização das primeiras escolas de direito representou uma derrota para o imperador.

Devemos avaliar se no momento da votação da lei fundadora das academias de direito no país as críticas dos parlamentares dirigidas à organização dos estudos em Coimbra foram traduzidas em rupturas com padrão português de ensino jurídico. Além dos estatutos portugueses, as matérias do currículo, chamadas pelos contemporâneos de "cadeiras", que estruturavam os estudos da Universidade de Coimbra e estavam presentes no projeto de lei em análise, também foram objeto de questionamentos, assim como os compêndios e o método de ensino. Duras críticas foram dirigidas ao ensino do direito romano que estruturava os estudos jurídicos desde a sua fundação em Portugal, no século XIII. Consideramos que a decisão da maioria de retirá-lo do projeto deve ser registrada como inovadora, assim como a supressão do curso jurídico canônico. Eram frequentes as afirmações de que as doutrinas romanas, vinculadas aos governos não representativos e "despóticos", não serviam para o país, pressupondo que este possuía as suas especificidades. Evidenciava-se, assim, uma nova forma de se olhar para a tradição, caracterizada pela possibilidade de diálogo com o legado jurídico português e não pela sua recepção automática. Ela foi influenciada pelo contexto político da época, marcado pelas críticas às tradições políticas/ jurídicas do Antigo Regime e pelo desgaste do imperador, e pela aposta na viabilização futura de um projeto político nacional, dentro dos moldes do constitucionalismo.

A inexistência de uma legislação, em Portugal e no Brasil, que garantisse a liberdade de comércio, põe em relevo o caráter inovador dos estudos de direito comercial, denominado de "mercantil e marítimo", ausentes do projeto inicial. Os estudos dos princípios do liberalismo econômico iam ser inaugurados na ordem jurídica pelas academias de

45 Referência às orientações de D. Pedro I consta nos Anais da Câmara dos Deputados, sessão 05 jul., p.52. 
direito. Da mesma maneira, a falta de previsão de estudos de direito romano na estrutura curricular contribuiria para a perda da sua eficácia na esfera da prática jurídica. Os parlamentares conheciam bem o relevante papel que o ensino jurídico desempenhava na conformação da prática jurídica nos países em que a maioria das profissões jurídicas era monopolizada pelos bacharéis em direito. Em suma, a lei também era planejada para ter repercussões no próprio direito português recepcionado no país em 1823, tentando acelerar a sua transição para um direito nacional. Nos seus discursos, os deputados projetavam a ideia de um novo perfil do ordenamento legal, composto por uma legislação nacional e codificada. Sabendo que inexistia na época um ambiente político e social favorável à codificação do direito privado, o Parlamento direcionou esses anseios políticos para o campo do ensino jurídico. Vale a pena registrar mais duas mudanças. Como era esperado, depois de várias falas influenciadas pela ideologia constitucional que desqualificava os governos absolutos como arbitrários e despóticos, foi introduzida a matéria "direito constitucional". Após longas polêmicas, a "história do direito pátrio" foi suprimida do projeto: o argumento que prevaleceu remetia à inconveniência política de se estudar nessa matéria a história do direito português. ${ }^{46}$

Apesar da situação do Brasil dos anos vinte dos Oitocentos ter sido representada por alguns parlamentares como nova em oposição à antiga, na qual eles próprios se viam como protagonistas de grande relevância, nem sempre esse espírito inovador predominou. Houve alguns desencontros entre as intenções dos parlamentares e a prática. Às vezes, a tradição portuguesa fazia-se presente, de forma refletida ou não, no momento de tomada de decisão. Neste sentido, destaca-se a manutenção das matérias de Direito Pátrio, Civil e Criminal, dedicadas ao estudo do direito português; a retomada da cadeira de Direito Natural no seu formato coimbrão; a opção pelo ensino com base em compêndios, cujo

46 Ver, em especial, essas discussões em Anais da Câmara dos Deputados, sessão 23 ago. 1826, p.263-266. 
conteúdo novamente seria controlado pelos poderes políticos; a adoção dos estatutos do visconde da Cachoeira muito próximos no seu conteúdo aos da Universidade de Coimbra; a manutenção da metodologia do direito e do seu ensino, e da concepção de ciência do direito predominante na estrutura do ensino jurídico português. Faz-se registro de que certas decisões, embora independentes da estrutura de ensino da Universidade de Coimbra, não eram necessariamente de espírito inovador. A decisão de adicionar o estudo de doutrinas sociais, como a economia política, nos estudos jurídicos visava a preservação das amplas funções que os juristas tradicionalmente desempenhavam na administração estatal e não a renovação da formação jurídica e das habilidades dos juristas. É importante acrescentar que algumas questões semelhantes relacionadas à modernização do currículo estavam sendo discutidas em Portugal nos anos vinte do Oitocentos, porém, não foram implementadas, pois a situação política, desde a invasão napoleônica, até a estabilização do governo constitucional, não favorecia tais intervenções.

\section{CONSIDERAÇÕES FINAIS}

Seria pouco provável que os primeiros cursos de direito no país nascessem plenamente independentes da tradição jurídica portuguesa, apesar de alguns anseios políticos nesse sentido. A inexistência de uma nação brasileira anterior à emancipação política de 1822 e o perfil do processo de independência dificultaram o rompimento com os padrões culturais herdados de Portugal. Ademais, a trajetória educacional da elite política reunida no Parlamento levava-a a adotar como principal referência na elaboração do modelo nacional das academias de direito a estrutura do ensino na Universidade de Coimbra. E mais, na elaboração do currículo os parlamentares não podiam ignorar o fato do direito vigente no país ser composto em grande parte pela legislação portuguesa.

Esse contexto, no entanto, não deve encobrir as peculiaridades da trajetória histórica do país no que diz respeito à fundação do ensino jurídico. A identificação dessas especificidades foi facilitada pela 
constatação de que o processo de elaboração de uma proposta de ensino jurídico compreendeu duas etapas diferentes - as discussões e deliberações da Assembleia Constituinte e da Assembleia Geral. A percepção desta distinção foi importante para o esclarecimento e a revisão de algumas ideias presentes na literatura sobre o tema, tanto sobre a relação das academias de direito com os processos de construção do Estado e da nação, como sobre o perfil das escolas — independentes ou não dos padrões portugueses de ensino.

Para José Murilo de Carvalho, "os cursos de direito eram criados à imagem do predecessor coimbrão" (2004, p.76). No decorrer da sua (re)conhecida pesquisa, Carvalho apresenta vários argumentos sobre as semelhanças entre as escolas: no Brasil, os cursos de Olinda e de São Paulo reproduziram o efeito buscado pela política colonial, ou seja, a centralização e a homogeneização da formação de elites; as escolas dos dois lados do Atlântico promoviam contatos pessoais entre os alunos de várias regiões e uma ideologia comum (facilitada pelo controle do governo central ao qual as escolas estavam submetidas) necessária para as tarefas de construção do Estado; a bipartição das escolas de direito no Brasil seria "antes uma concentração do que o oposto" (2004, p.82). A avaliação de Carvalho tem como embasamento central os objetivos dos cursos jurídicos; as diferenças nas matérias que compõem o currículo são reconhecidas mas a eles é atribuído valor secundário. Já a presente pesquisa, embora em forte sintonia com essas ideias, constatou e reconheceu a importância de uma nova atitude das elites políticas da primeira legislatura - a de estabelecer, a partir de 1826, um diálogo com a tradição jurídica portuguesa e não a de recepcioná -la de forma mecânica.

A prática de vincular a formação universitária e, em especial, a jurídica às carreiras no Estado foi mantida também pela Assembleia Geral, 
dando-se continuidade ao modelo luso de formação e ocupação dos funcionários, agora a partir de um currículo modernizado. A urgente criação dos cursos foi coerente, portanto, com as demandas políticas e institucionais de formação do Estado. No que tange à formação da identidade nacional, à diferença dos deputados constituintes que não tinham despertado para essa possível dimensão do projeto das futuras academias, em 1826 torna-se perceptível o surgimento de novas representações do passado capazes de criar um certo distanciamento da cultura portuguesa. Setores da elite política perceberam a importância da autonomização cultural no processo de construção da nação. Entretanto, na nossa avaliação, não chegam a concretizar um projeto autônomo da cultura jurídica portuguesa. Este ficou mais no plano discursivo e formal, já que bastante preocupado com a adjetivação "nacional" e não com a produção de uma regulamentação própria, com objetivos e conteúdos diferenciados. O pressuposto de que estavam em curso no mundo ibérico do Oitocentos revoluções políticas mas não jurídicas (Slemian; Carriga, 2013) também parece adequado para a nossa pesquisa: as mudanças no ensino do direito no período pesquisado seriam melhor caracterizadas como reformas e não como rupturas com a tradição existente.

Percebe-se que a relação entre a tradição jurídica portuguesa e as expectativas de superá-la foi complexa. Ao mesmo tempo em que se inovou em alguns aspectos relevantes na organização dos estudos, a tradição foi em parte mantida. Neste sentido, abordagens dicotômicas, que procuram colocar em oposição rígida tradição e modernidade, não ajudam na compreensão das sutilezas presentes no debate e nas decisões políticas sobre a criação dos primeiros cursos jurídicos no Brasil. Neste caso, como em outros, novas pistas surgem a partir da procura de peculiaridades em processos onde tradição e modernidade, ao contrário de se excluírem, cruzam-se em formas peculiares de renovação e manutenção de ideias e valores. 
Anexo I - Lista dos deputados constituintes, em ordem alfabética, que participaram da discussão do projeto de criação de universidades e cursos jurídicos no território nacional.

\begin{tabular}{|c|c|c|c|}
\hline Deputado Constituinte 1823 & Província & $\begin{array}{l}\text { Formação } \\
\text { Superior }\end{array}$ & $\begin{array}{l}\text { Profissão } \\
\text { /Ocupação }\end{array}$ \\
\hline $\begin{array}{l}\text { 1. Antônio Carlos Ribeiro de Andrada } \\
\text { Machado e Silva }\end{array}$ & SP & $\begin{array}{l}\text { Direito } \\
\text { Filosofia (UC) }\end{array}$ & Magistrado \\
\hline 2. Antônio Gonçalves Gomide & MG & $\begin{array}{l}\text { Medicina } \\
\text { (UC) }\end{array}$ & Medico \\
\hline 3. Antônio Luis Pereira da Cunha & RJ & Direito (UC) & Magistrado \\
\hline 4. Caetano Maria Lopes Gama & $\mathrm{AL}$ & Direito (UC) & $\begin{array}{l}\text { Magistrado } \\
\text { Advogado }\end{array}$ \\
\hline 5. Cândido José de Araujo Viana & MG & Direito (UC) & Magistrado \\
\hline 6. Francisco Jê Acaiaba de Montesuma & $\mathrm{BA}$ & Direito (UC) & Advogado \\
\hline 7. Francisco Muniz Tavares & $\mathrm{PE}$ & $\begin{array}{l}\text { Teologia } \\
\text { (Un. Paris) }\end{array}$ & $\begin{array}{l}\text { Padre, escritor, } \\
\text { Historiador }\end{array}$ \\
\hline $\begin{array}{l}\text { 8. Joaquim Manuel } \\
\text { Carneiro da Cunha }\end{array}$ & $\mathrm{PB}$ & Sem formação & $\begin{array}{l}\text { Proprietário } \\
\text { de terras }\end{array}$ \\
\hline 9. José Arouche de Toledo Rendon & SP & Direito (UC) & $\begin{array}{l}\text { Militar, advogado, } \\
\text { Proprietário } \\
\text { de terras }\end{array}$ \\
\hline 10. José da Silva Lisboa & BA & $\begin{array}{l}\text { Direito } \\
\text { Filosofia (UC) }\end{array}$ & $\begin{array}{l}\text { Magistrado } \\
\text { Professor }\end{array}$ \\
\hline 11. José Feliciano Fernandes Pinheiro & RS & Direito (UC) & Magistrado \\
\hline $\begin{array}{l}\text { 12. José Martiniano Pereira } \\
\text { de Alencar }\end{array}$ & CE & $\begin{array}{l}\text { Formação } \\
\text { eclesiástica } \\
\text { (Seminário } \\
\text { de Olinda) }\end{array}$ & Sem dados \\
\hline $\begin{array}{l}\text { 13. José Teixeira } \\
\text { da Fonseca Vasconsellos }\end{array}$ & MG & Direito (UC) & $\begin{array}{l}\text { Magistrado } \\
\text { Proprietário } \\
\text { de terras }\end{array}$ \\
\hline 14. Lúcio Soares Teixeira Gouvêa & MG & Direito (UC) & Magistrado \\
\hline 15. Luis José de Carvalho e Mello & $\mathrm{BA}$ & Direito (UC) & Magistrado \\
\hline $\begin{array}{l}\text { 16. Manuel Caetano de Almeida } \\
\text { e Albuquerque }\end{array}$ & $\mathrm{PE}$ & Direito (UC) & Magistrado \\
\hline
\end{tabular}




\begin{tabular}{|c|c|c|c|}
\hline Deputado Constituinte 1823 & Província & $\begin{array}{l}\text { Formação } \\
\text { Superior }\end{array}$ & $\begin{array}{l}\text { Profissão } \\
\text { /Ocupação }\end{array}$ \\
\hline 17. Manuel Ferreira da Camara & MG & $\begin{array}{l}\text { Direito } \\
\text { Filosofia } \\
\text { (UC) } \\
\text { Mineralogia* }\end{array}$ & $\begin{array}{l}\text { Engenheiro } \\
\text { Proprietário } \\
\text { de terras }\end{array}$ \\
\hline 18. Manuel Jacinto Nogueira da Gama & RJ & $\begin{array}{l}\text { Matemática } \\
\text { Filosofia (UC) }\end{array}$ & $\begin{array}{l}\text { Militar } \\
\text { professor }\end{array}$ \\
\hline 19. Manuel José de Souza França & RJ & Direito (UC) & Sem dados \\
\hline 20. Miguel Calmon du Pin e Almeida & $\mathrm{BA}$ & Direito (UC) & Diplomata \\
\hline $\begin{array}{l}\text { 21. Nicolau Pereira } \\
\text { de Campos Vergueiro }\end{array}$ & SP & Direito (UC) & $\begin{array}{l}\text { Magistrado } \\
\text { Advogado } \\
\text { Proprietário } \\
\text { de terras }\end{array}$ \\
\hline 22. Pedro de Araujo Lima & PE & Direito (UC) & $\begin{array}{l}\text { Magistrado } \\
\text { Jornalista } \\
\text { Proprietário } \\
\text { de terras }\end{array}$ \\
\hline 23. Pedro José da Costa Barros & $\mathrm{CE}$ & Sem formação & Militar \\
\hline 24. Venâncio Henrique de Resende & $\mathrm{PE}$ & $\begin{array}{l}\text { Formação } \\
\text { eclesiástica }\end{array}$ & Padre \\
\hline
\end{tabular}

\section{Observações}

1. Estão em negrito os nomes que os deputados adotaram na Assembleia Constituinte.

2. A província indicada corresponde à província que os deputados representam na Assembleia Constituinte.

3. Na coluna de formação superior não foi feita distinção entre os cursos de direito civil e direito canônico. Ambos foram colocados como "Direito". Somente foi considerado o curso completo.

4. * Manuel Ferreira da Câmara se formou mineralogia na Universidade de Freiberg.

5. Para os padres foi indicada "formação eclesiástica", considerada formação superior.

6. A tabela foi construída pela autora, com base em informações extraídas de sítios públicos da internet: www.senado.gov.br; www.camara.gov.br; www.stf.jus.br; www. cpdoc.fgv.br; www.cbg.org.br; também foi utilizado um sítio acadêmico, www. consciencia.org; Acesso em: 09 maio 2014. 


\section{Agradecimentos}

A autora agradece ao Programa de Pós-Graduação em História da Universidade de Brasília.

\section{REFERÊNCIAS BIBLIOGRÁFICAS}

ADORNO, Sergio. Os aprendizes do poder. O bacharelismo liberal na política brasileira. Rio de Janeiro: Paz e Terra, 1988.

BASTOS, Aurélio Wander (coord.). Os cursos jurídicos e as elites políticas brasileiras. Brasília: Câmara dos Deputados. Centro de Documentação e Informação, 1978.

CARVALHO, José Murilo de. A construção da ordem. Teatro das sombras. Rio de Janeiro: Civilização Brasileira, 2004.

CARVALHO, José Murilo de (org.). Nação e cidadania no Império: novos horizontes. Rio de Janeiro: Civilização Brasileira, 2007.

CHARLE, Chistophe; VERGER, Jacques. História das universidades. São Paulo: Unesp, 1996.

DOLHNIKOFF, Miriam. O pacto imperial: origens do federalismo no Brasil do século XIX. São Paulo: Globo, 2005.

GRINBERG, Keila. Código Civile Cidadania. Rio de Janeiro: Jorge Zahar, 2001. HESPANHA, Antonio Manuel. O caleidoscópio do direito. O direito e a justiça nos dias e no mundo de hoje. Coimbra: Almedina, 2007.

HESPANHA, Antonio Manuel. Pequenas repúblicas, grandes Estados. Problemas de organização política entre Antigo Regime e liberalismo. In: JANCSÓ, István (org.). Brasil: formação do Estado e da nação. São Paulo: Hucitec; Inijuí; Fapesp, 2003. p.93-108.

JANCSÓ, István; PIMENTA, João Paulo. Peças de um mosaico (ou apontamentos para o estudo da emergência da identidade nacional brasileira). In: MOTA, Carlos Guilherme (org.). Viagem incompleta. A experiência brasileira. São Paulo: Senac, 2009. p.127-175.

KIRSCHNER, Tereza Cristina. José da Silva Lisboa, Visconde de Cairu: itinerários de um ilustrado luso-brasileiro. São Paulo: Almedina; Belo Horizonte: PUC-Minas, 2009. 
KOSELLECK, Reinhart. Futuro passado. Contribuição à semântica dos tempos históricos. Rio de Janeiro: Contraponto: PUC-Rio, 2006.

KOSELLECK, Reinhart. Time and history. In: KOSELLECK, Reinhart. The practice of conceptual history. Timing history, spacing concepts. Stanford: Stanford University Press, 2002. p.100-114.

LYNCH, Christian Edward Cyril. Da monarquia à oligarquia. História institucional e pensamento político brasileiro (1822-1930). São Paulo: Alameda, 2014.

LYNCH, Christian Edward Cyril. O discurso político monárquico e a recepção do conceito de poder moderador no Brasil (1822-1824). Dados - Revista de Ciências Socias, vol. 48, n. 3, p.611-654, 2005.

MALERBA, Jurandir. Esboço crítico da recente historiografia sobre a independência (1980-2002). In: MALERBA, Jurandir (org.). A independência brasileira: novas dimensões. Rio de Janeiro: FGV, 2006. p.19-52. MAXWELL, Kenneth. Chocolate, piratas e outros malandros - ensaios tropicais. Rio de Janeiro: Paz e Terra, 1999.

NEVES, Lúcia Maria Bastos Pereira das. Corcundas e Constitucionais: cultura e política (1820-1823). Rio de Janeiro: Revan: FAPERJ, 2003.

NEVES, Lúcia Maria Bastos Pereira das. Estado e Política na independência. In: GRINBERG, Keila; SALLES, Ricardo (orgs.). O Brasil Imperial: 18081831, vol. I. Rio de Janeiro: Civilização Brasileira, 2009a. p.95-136.

NEVES, Lúcia Maria Bastos Pereira das. Constituição. Usos antigos e novos de um conceito no Império do Brasil (1821-1860). In: CARVALHO, José Murilo; NEVES, Lúcia Maria Bastos Pereira das. Repensando o Brasil do Oitocentos. Rio de Janeiro: Civilização Brasileira, 2009b. p.183-205. PEDREIRA, Jorge Miguel. Economia e Política na explicação da independência do Brasil. In: MALERBA, Jurandir (org.) A independência brasileira: novas dimensões. Rio de Janeiro: FGV, 2006. p.55-98.

RIBEIRO, Gladys Sabina; PEREIRA, Vantuil. O Primeiro Reinado em revisão. In: GRINBERG, Keila; SALLES, Ricardo (orgs.). O Brasil Imperial vol. I.: 1808-1831. Rio de Janeiro: Civilização Brasileira, 2009. p.137-173.

SCHIAVINATTO, Iara Lis. Entre histórias e historiografias: algumas tramas do governo joanino. In: GRINBERG, Keila; SALES, Ricardo (org.). Brasil 
imperial: 1808-1831, vol. I.. Rio de Janeiro: Civilização Brasileira, 2009. p.55-93.

SCHWARCZ, Lilia Moritz. O espetáculo das raças: ciência, instituições e questão racial no Brasil. São Paulo: Companhia das Letras, 1993.

SILVA, Maria Beatriz Nizza da (coord.). Dicionário da colonização portuguesa no Brasil. Lisboa: Verbo, 1994.

SLEMIAN, Andréa. Sob o império das leis: Constituição e unidade nacional na formação do Brasil (1822-1834). Tese (Doutorado em História) - Universidade de São Paulo. São Paulo, 2006. Disponível em: http://www.teses. usp.br/teses/disponiveis/8/8138/tde-13072007-14942/publico/TESE_ ANDREA_SLEMIAN.pdf.

SLEMIAN, Andréa; CARRIGA, Carlos. Em trajes brasileiros: justiça e constituição na América ibérica (1750-1850). Revista Histórica, n. 169, p.181-221, jul./dec. 2013.

VENANCIO FILHO, Alberto. Das arcadas ao bacharelismo. (150 anos de ensino jurídico no Brasil). São Paulo: Perspectiva, 1982. 